\author{
Journal of Politics \& Governance \\ Vol. 8 No. 10, October 2020, Pp. 4-6 \\ ISSN: 2278473X (Print) 2456-8023 (Online) \\ DOI: https://doi.org/10.47914/jpg.2020.v08i10.001
}

\title{
Editorial: Revisiting Liberty
}

\author{
Sudarshana Jha*
}

\begin{abstract}
Concept of liberty is quite fascinating. People have been idealizing with the notion of liberty since ancient times. It is become all the more significant in contemporary times when the information and communication technologies as well as internet of things of entered all walks of life of human being even at the risk of breaching their privacy and trust. This article is based on reflections of a young scholar about the idea of liberty and that is impacting our day-to-day life and living in the fast changing world. While exploring the meaning of liberty, the scholar is raising a few questions that need the attention of other researchers.
\end{abstract}

KEYWORDS: Liberty, Rights, Justice, Fairness, Freedom

My thoughts spin a tale - a story of land beyond imagination, a story that is very real. My mind is

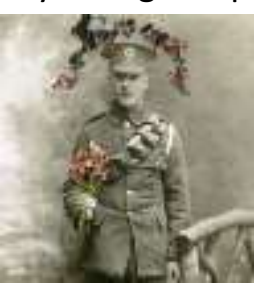
untethered, unbound and free. However, I am not. There is an agonising pull towards freedom, yet my feet are bound on this planet. What is liberty? I wonder if it is escaping reality or if it is merely a wishful dream fabricated by those who do not wish to seek the land beyond reality. True freedom is an unachievable goal which all the creatures have always aspired. The truth of liberty is as confusing as it is uncomplicated. Each creature on this planet has a different idea of liberty, a word used by many. It is the inherent nature of life to strive towards freedom and liberty, to be away from forces which make us submit to external whims. For a caged bird, liberty may be to soar in the skies for an animal in a hunter's trap; liberty is to be set free, as for me, I am still searching for my true meaning of liberty.

On this search, I came across numerous ancient texts which talk about natural justice, human nature and the laws of the wild. Some claim that true liberty lies with the forests and the grasslands, in the golden age of the titan Cronos. Many wonder if ignorance of human suffering truly is liberty. The Indian constitution proudly displays the word "liberty" in the first few pages, making it one of the pillars of the complicated democratic system. I cannot help but wonder if liberty can truly be limited to the idea of being able to speak without fear. An interesting take was by MacCallum, who sees

\footnotetext{
*Free Lance Writer based in New Delhi E-mail: sudarshanajha@gmail.com
} 


\section{Journal of Politics \& Governance, Vol. 8, No. 10, October 2020}

liberty as a single concept: "it resides in acting to do or to refrain from doing something, always against some constraint, interference or impediment." Liberty, a phenomenon which even the beasts of wild crave should not be limited to a mere political definition.

The idea of liberty is quite a confounding one. For, it was created by the very beings who took it away. Is it true that one never realises the actual value of liberty until they lose it? I may never know. Liberty is one of the most potent weapons of the mind. One can contain the body, but the mind will always traverse beyond the realm of reality it physically is present in. Liberty is the flagbearer of revolution. Liberty grants people power. Liberty enables people to dream, to speak. Liberty is the weapon of masses which crush their oppressor. Liberty will always exist in the realm of reality which the mind can comprehend. This realm is a result of interwoven nuances which live in and around one. There is only a limited degree to which one's mind can understand liberty. Yet it is enough. Liberty exists in the bleakest of situations; liberty lives in the minds of the most oppressed groups; liberty is a state of mind which is achieved when one starts fighting for it. Liberty unravels the very fabric of society it has created. There is a fragile line between liberty and chaos. What stops societies from going in frenzy, then?

"Isaiah Berlin's concept of liberty comprises two poles: negative liberty and positive liberty. The concept of positive liberty involves the idea of citizens taking action for their reasons and not from external causes; it is a liberty to do something (BERLIN, 1969a, p. 131-134). Negative liberty, meanwhile, has to do with the sphere where citizens are free of any interference from other individuals or collective subjects (Berlin, 1969, p. 122-123 quoted by Crover, 2014). The realm of the living is, unfortunately, not black and white. There are no clear distinctions between right and wrong. There is no distinction between chaos and order. Liberty exists within numerous permutations and combinations of the two. As aforementioned, there is no set definition of this widely thrown around the word. Liberty is the force which keeps the masses sane and safe. Yet too much of it can end the society as we know. Should there a concept as "too much liberty"? In the words of Barry Goldwater, "Extremism in defence of liberty is no vice. And moderation in the pursuit of justice is no virtue."

As much of a patron of liberty one may be, there always will exist restrictions on liberty. The amalgamation of mind and society creates these chains. Us human beings exist within these selfmade chains of order and culture; it is our reality. I am no connoisseur to say if this is fortunate or not. A fish lives in a glass case most of their life. Is the glass case engaging them? Yes. But it also sustains their life force. To break out of the glass cage would be foolish. A beast is captured and trained for entertainment. The creature escapes and lives the rest of their life in the wild, free. Should one attempt to break the chains which withhold true liberty? There are life-sustaining restrictions placed on many of us. One may even dare to call it common sense.

It truly is confounding how a single word could spark up such a long train of thought in one's mind. The idea of liberty entails the notion of freedom. Many define liberty as "the state of being free within society from oppressive restrictions imposed by authority on one's way of life, behaviour, or political views." This definition does not satiate my curiosity. I wonder if one is foolish to search for freedom while knowing one is always bound to social norms. The desire for liberty exists in our mind and hearts; it would be impossible to give up the search for liberty. Table 1 provides a glimpse of the notion of liberty through the ages. 
Table 1: Liberty through the Ages

\begin{tabular}{|l|l|}
\hline Age & Idea of Liberty \\
\hline Ancient Greece & $\begin{array}{l}\text { "Aristotle's (384-322 B.C.E.) definition of liberty resembles the contemporary } \\
\text { notion; for him, the general essence of freedom is being one's person for } \\
\text { one's own sake rather than belonging to another." (Science Jrank, n.d.) }\end{array}$ \\
\hline Ancient Rome & $\begin{array}{l}\text { Roman liberty was by definition a positive right that was guaranteed (but } \\
\text { could also be withdrawn) by the law. Law-abiding citizens enjoyed the liberty } \\
\text { of a Roman citizen and, before the law, all the citizens were equal. (Science } \\
\text { Jrank n.d.) }\end{array}$ \\
\hline Early Christianity & $\begin{array}{l}\text { St. Augustine of Hippo's (354-430 C.E.) discourse on freedom revolved } \\
\text { around the idea of free will. }\end{array}$ \\
\hline Medieval Age & $\begin{array}{l}\text { A liberty was an English unit originating in the Middle Ages, traditionally } \\
\text { defined as an area in which regalian right was revoked and where the land } \\
\text { was held by a mesne lord (i.e. an area in which rights reserved to the king had } \\
\text { been devolved into private hands). (Tomlins et al. 1804) }\end{array}$ \\
\hline Renaissance & $\begin{array}{l}\text { Liberty is conceived as city-state autonomy, and free people is one that is Sibi } \\
\text { princeps, i.e., not under the jurisdiction of foreign powers and is living under } \\
\text { its laws. To maintain its freedom, a community needs to defend itself from } \\
\text { foreign enemies. (Terravecchia, 2019) }\end{array}$ \\
\hline Modern age & $\begin{array}{l}\text { In modern politics, liberty is the state of being free within society from control } \\
\text { or oppressive restrictions imposed by authority on one's way of life, } \\
\text { behaviour, or political views. (Lexio) }\end{array}$ \\
\hline
\end{tabular}

[Source: Compilation by the author]

I am always wondering when the human civilisation will achieve true liberty. There is a multitude of methods via which the word liberty can be interpreted. Perhaps our civilisation has already achieved liberty, and we are unaware or unsure. Is liberty always beyond the laws of man? Can one find liberty within a tiny cell of a prison? Is liberty achieved by masses any different from a person achieving liberty in his/her mind? Can a poor person ever experience liberty? Is liberty meant only for the rich and the elite?

\section{Reference}

Blackman J (2020). Reason- Free Minds and Free Markets Accessed from https://reason.com/2020/06/16/senator-hawley-bostock-represents-the-end-of-theconservative-legal-movement/

Coser I (2014). A Journal of Brazilian Political Science Association. Journal, 8 (3), Accessed fromhttps://www.scielo.br/pdf/bpsr/v8n3/1981-3821-bpsr-8-3-0039.pdf

Lexico [N.D.] Oxford. Accessed from- https://www.lexico.com/en/definition/liberty

Science Jrank [N.D.] Accessed from- https://science.jrank.org/pages/9964/Liberty-AncientConceptions.html

Terravecchia GP [2019]. Encyclopaedia of renaissance philosophy. DOI: https://doi.org/10.1007/9783-319-02848-4_605-1

Tomlins, T. E., Raithby, J., Simons, N., Bevan, C. D., \& Rickards, G. K. (Eds.). (1804). The Statutes of the United Kingdom of Great Britain and Ireland (Vol. 1). G. Eyre and A. Strahan, printers to the King. 